\title{
Akne ve Diyet
}

๑ Prof. Dr. Göksun Karaman

Aydın Adnan Menderes Üniversitesi Tıp Fakültesi, Emekli Öğretim Üyesi, Aydın, Türkiye

Öz

Beslenme şeklinin ve bazı gıdaların aknenin başlaması veya şiddetlenmesinde rolü olduğu yaygın bir inanıştır. Son yıllarda özellikle karbonhidrat yükü fazla olan gıdaların ve süt ürünlerinin etkisi üzerinde durulmaktadır. Tam ve yarım yağlı sütün postprandiyal hiperinsülinemi, insülin benzeri büyüme faktörü-1 artışı ve rapamisin protein kompleksinin memeli hedefi-1 aktivasyonuna neden olduğu ve akneyi şiddetlendirdiği düşünülmektedir. Batı tipi beslenmenin yaygınlaşması ile artan karbonhidrat içeriği yüksek gıdalar da hiperinsülinemiye neden olarak testosteron seviyesinde artış ve seks hormonu bağlayıcı globülinde azalmaya neden olur. Bu beslenme şeklinin özellikle adölesan çağdaki kişilerde çok kabul gördüğü ve bu yaşlarda düzensiz ve dengesiz beslenmenin çok arttığı da bir gerçektir. Diyet ve akne arasındaki bu ilişkinin hastalarla paylaşılması ve düzenli beslenmenin özendirilmesi akne tedavisinde başarımızı artıracaktır.

Anahtar Kelimeler: Akne vulgaris, beslenme, hiperinsülinemi

\begin{abstract}
Common belief is that eating habits and some foods have a role in the onset or aggravation of acne. Especially the effects of foods with a high carbohydrate load and dairy products have been considered recently. Whole and semi-skimmed milk is thought to cause postprandial hyperinsulinemia, increased insulin-like growth factor-1 and mechanistic target of rapamycin complex-1 activation and to aggravate acne. Foods with high carbohydrate content involved in popular Western diets cause hyperinsulinemia, resulting in elevated testosterone levels and reduced sex hormone-binding globulin. It is a fact that this type of eating is widely accepted especially among adolescents, making irregular and unbalanced nutrition much more common at these ages. Communicating this relationship between diet and acne to patients and promoting proper diets will increase our success in treating acne.
\end{abstract}

Keywords: Acne vulgaris, nutrition, hyperinsulinemia

\section{Giriş}

Aknenin klasik patogenetik mekanizmasında beslenme şekli ve metabolizma yer almamakla beraber akne ile diyet arasındaki ilişki uzun yıllardır yoğun ilgi çekmektedir. Epidemiyolojik çalışmalar batı tipi beslenmenin yerleşmediği endüstrileşmemiş toplumlarda ve kırsal kesimde yaşayan kişilerde aknenin daha az görüldüğünü bildirmektedir. Geleneksel beslenme sırasında akne oluşmayan Eskimolarda modern hayata geçiş sonrasında akne prevalansının batılı toplumlarla benzer hale geldiği; ekonomik olarak güçlü ülkelerde ve kırsal kesime göre şehirde yaşayanlarda aknenin daha fazla görüldüğü de gözlenmiştir ${ }^{1}$.

Batı tipi beslenme avcılıktan yerleşik yaşam ve tarımsal gıda üretimine geçiş sonrasında giderek yerleşen ve sanayileşme ile beraber işlenmiş gıdalar, katkı maddeleri ve özellikle basit şeker olmak üzere karbonhidrat içeriği artan beslenme

Yazıșma Adresi/Address for Correspondence: Prof. Dr. Göksun Karaman Aydın Adnan Menderes Üniversitesi Tıp Fakültesi, Emekli Öğretim Üyesi, Aydın, Türkiye E-posta: goksunkaraman@hotmail.com ORCID: orcid.org/0000-0003-3018-8836

(c) Telif Hakkı 2020 Deri ve Zührevi Hastalılar Derneği

Türkderm - Türk Deri Hastalıkları ve Frengi Arșivi, Galenos Yayınevi tarafından basılmıștır. 
şeklidir. Bu beslenme şeklinin yerleşmesi sonrasında iştah artışı ve obezite, dislipidemi, diyabet ve diğer metabolik problemler giderek artmıştır. Beslenme alışkanlıklarındaki değişikliklerin kızlarda menarş yaşını giderek aşağı çektiği, bunun da hormonal etkinin daha erken başlaması sonucunu getirdiği vurgulanmaktadır².

Yüksek glisemik indeksi olan gıdaların akneyi artırdığı, glisemik yükü düşük olan beslenme ile akne şiddetinde azalma saptandığı ile ilgili kuvvetli veriler bulunmaktadır ${ }^{3}$. Otuz iki akne hastasına 10 hafta boyunca düşük glisemik yük içeren diyet uygulanan ve 15 kişilik kontrol grubu ile karşılaştırılan bir çalışmada; hem akne şiddetinde hem de histopatolojik olarak sebase bez büyüklüğünde ve lezyonlardaki enflamatuvar hücre ve sitokin miktarında azalma olduğu saptanmıştır ${ }^{4}$. Benzer şekilde 43 erkek hastaya 12 hafta uygulanan düşük glisemik yüklü diyet sonrasında akne lezyonlarında belirgin gerileme izlendiği bildirilmiştir ${ }^{5}$.

Akne vulgarisin (AV) başlangıcının puberte ile uyumlu olduğu bilinmektedir. Hormonal etkinin ortaya çıkması ile sebum miktarında artış olması AV'nin patogenezinde önemli basamaklardan birisidir. İnsülin, glukokortikoidler, östrojen, tiroid hormonları gibi pek çok hormonun pilosebase ünitenin gelişmesi, diferansiyasyonu ve hastalıklarında rol aldığı bilinmesine karşın, kilit rol androjenlerdedir. Batı tipi beslenmede öne çıkan yüksek glisemik yükü olan diyet hiperinsülinemiye neden olmaktadır. Hiperinsülinemi testosteron seviyesinde artış ve seks hormonu bağlayıcı globülinde azalmaya neden olur. Serbest dolaşımda artan steroid seks hormonlarının periferal dokularda insülin direncine neden olduğu ve oluşan karşılıklı etkileşmenin bir kısır döngüye neden olduğu belirtilmektedir ${ }^{2,3}$.

Insülin androjenlerin etkisini artırmanın yanı sıra, karaciğerde insülin benzeri büyüme faktörü-1'in (IGF-1) yapımını artırır ve IGF bağlayıcı proteini azaltır. IGF-1 overler, adrenal ve testislerde androjen sentezinin artmasına neden olur. IGF-1'in arttığı prematüre menarş, polikistik over sendromu ve akromegali gibi endokrin hastalıklarda akne prevalansının arttığı görülmektedir. Insülin ve IGF-1 kıl folikülünün ve sebositlerin gelişmesine ve androjenlerin etkisinin artmasına katkı sağlamaktadır ${ }^{5}$. Bunun yanında glisemik indeksi yüksek veya düşük olan diyet uygulamasının akne şiddetinde değişiklik yaratmadığını; akneli hastaların kontrol grubuna göre insülin ve IGF-1 düzeylerinde fark olmadığını bildiren çalışmalar da vardır ${ }^{6,7}$

Süt ve süt ürünlerinin AV'de artışa neden olabileceği üzerine çalışmalar vardır. Önceleri yağı alınmış sütün etkisi üzerinde durulurken zaman içinde fazla miktarda tam yağlı süt ürünlerinin (süt, kefir ve yoğurt) tüketimi ile orta ve şiddetli akne oluşumu arasında ilişki olduğu bildirilmiştî8-10. Tam ve yarım yağlı sütün postprandiyal hiperinsülinemiye; pastörize günlük sütün IGF-1 artışına; yoğurt, dondurma, sporcuların kullandığı peynir altı suyu ve kazein gibi protein tozlarının rapamisin protein kompleksinin memeli hedefi-1 (mTORC1) aktivasyonuna neden olduğu savunulmaktadır ${ }^{11}$. Sebze, meyve ve balık yiyen kişilerde akneye daha az rastlandığı yönünde de sonuçlar bildirilmektedir ${ }^{12-15}$. Antioksidanlar, balık yağı, çinko ve probiyotikler ile ilgili yeterli veri bulunmamaktadır. Karbonhidrat ve şeker içeriği yüksek batı tipi beslenmenin, süt ve süt ürünlerinin fazla tüketiminin insülini, IGF-1'i ve mTORC1'in sinyalini artırarak akne patogenezinde rol oynadığı bilinmektedir. AV'nin obezite, tip-2 diyabet, kanser gibi mTORC1 ile ilişkili hastalıkların bir parçası olduğu ve pilosebase ünitenin metabolik sendromu olarak kabul edilmesi gerektiği bildirilmiştir ${ }^{11}$. Ancak bu hipotezi destekleyecek çalışmalara intiyaç bulunmaktadır.
Ülkemizde tüm Türkiye'yi temsil edecek şekilde 7 bölgeden, toplam 26 merkezde 3.837 akne hastasının katıldığı çok merkezli bir çalışmada vücut kitle indeksi ile akne şiddeti arasında ilişki olduğu saptanmıştır. Diyet alışkanlıkları da sorgulanan katıımcılarda çikolata, beyaz ekmek, çay, süt ürünleri, beyaz şeker, muz, karpuz, mısır cipsi, elma ve portakal tüketimi ile akne şiddeti arasında ilişki olduğu tespit edilmiştir. Balık, kırmızı et, patates, makarna, nohut, fasulye, mercimek, tam buğday ekmeği tüketenlerde ise akne şiddetinin daha az olduğu rapor edilmiştir. Haftada 3 porsiyondan fazla çikolata, süt ürünü, çay, patates tüketenlerde şiddetli akne görülme oranının yüksek olduğu; haftada 3 porsiyondan fazla balık, kırmızı et ve mercimek tüketenlerde ise aknenin daha hafif seyrettiği belirtilmiştir. Bu veriler tüketilen ürünlerle akne şiddeti arasında ülkemizde de bir ilişki olduğunu ve hastalarımıza diyet konusunda yol gösterici olmamız gerektiğini düşündürmektedir ${ }^{16}$. Diyetin AV üzerine etkisi halen tartışmalıdır, ancak artan veriler giderek bu konunun önemini göstermeye başlamıştır. Batı tipi yüksek glisemik indeksi olan yiyeceklerin özellikle adölesan çağdaki kişilerde çok kabul gördüğü ve bu yaşlarda düzensiz ve dengesiz beslenmenin çok arttığı da bir gerçektir. Bu durumda özellikle yüksek glisemik indeksi olan yiyeceklerin olası rolü hasta ile paylaşılmalı, süt ürünleri konusunda da uyarıda bulunulmalıdır (Tablo 1).

\begin{tabular}{|c|c|}
\hline \multirow{10}{*}{$\begin{array}{l}\text { Yüksek } \\
\text { glisemik } \\
\text { yükü olan } \\
\text { gıdalar* }\end{array}$} & Şeker ve glukoz şurubu içeren gıdalar \\
\hline & Unlu gidalar (ekmek, makarna, vs.) \\
\hline & Patates \\
\hline & Havuç \\
\hline & Pirinç \\
\hline & Mısır gevreği \\
\hline & Şeker içeriği yüksek olan meyveler (karpuz, üzüm, muz) \\
\hline & İşlenmiş gıdalar \\
\hline & Enerji içecekleri \\
\hline & Protein tozları \\
\hline \multirow{4}{*}{$\begin{array}{l}\text { Süt ve süt } \\
\text { ürünleri }\end{array}$} & Süt (yağ miktarından bağımsız) \\
\hline & Sanayi tipi maya ile yapılan peynir, yoğurt, kefir \\
\hline & Dondurma \\
\hline & Peynir altı suyu \\
\hline
\end{tabular}

*https://www.health.harvard.edu/diseases-and-conditions/glycemicindex-and-glycemic-load-for-100-foods

\section{Kaynaklar}

1. Melnik BC: Acne vulgaris: The metabolic syndrome of the pilosebaceous follicle. Clin Dermatol 2018;36:29-40.

2. Wolf R, Matz H, Orion: Acne and diet. Clin Dermatol 2004;22:387-93.

3. Çerman AA, Aktaş E, Altunay K, ArıCı JE, Tulunay A, Ozturk FY: Dietary glycemic factors, insulin resistance, and adiponectin levels in acne vulgaris. J Am Acad Dermatol 2016;75:155-62.

4. Kwon $\mathrm{HH}$, Yoon JY, Hong JS, Jung JY, Park MS, Suh DH: Clinical and histological effect of a low glycaemic load diet in treatment of acne vulgaris in Korean patients: A randomized, controlled trial. Acta Derm Venereol 2012;92:241-6.

5. Smith RN, Mann NJ, Braue A, et al: The effect of a high-protein, low glycemicload diet versus a conventional, high glycemic-load diet on biochemical 
parameters associated with acne vulgaris: a randomized, investigator masked, controlled trial. J Am Acad Dermatol 2007;57:247-56.

6. Reynolds R, Lee S, Choi JY, et al: Effect of the glycemic index of carbohydrates on acne vulgaris. Nutrients 2010;2:1060-72

7. Kaymak Y, Adisen E, Ilter N, Bideci A, Gurler D, Celik B: Dietary glycemic index and glucose, insulin, insulin-like growth factor-l, insulin-like growth factor binding protein 3, and leptin levels in patients with acne. J Am Acad Dermatol 2007:57:819-23.

8. Adebamowo CA, Spiegelman D, Danby FW, Frazier AL, Willett WC, Holmes MD: High school dietary dairy intake and teenage acne. J Am Acad Dermatol 2005;52:207-14.

9. Ismail NH, Manaf ZA, Azizan NZ: High glycemic load diet, milk and ice cream consumption are related to acne vulgaris in Malaysian young adults: a case control study. BMC Dermatol 2012;12:13.

10. Ulvestad M, Bjertness $E$, Dalgard F, Halvorsen JA: Acne and dairy products in adolescence: results from a Norwegian longitudinal study. J Eur Acad Dermatol Venereol 2017;31:530-5.
11. Melnik BC: Linking diet to acne metabolomics, inflammation, and comedogenesis: an update. Clin Cosmet Investig Dermatol 2015;8:371-88.

12. Di Landro, Cazzaniga S, Parazzini F, et al: Family history, body mass index, selected dietary factors, menstrual history, and risk of moderate to severe acne in adolescents and young adults. J Am Acad Dermatol 2012;67:112935.

13. Jung JY, Yoon MY, Min SU, et al. The influence of dietary patterns on acne vulgaris in Koreans. Eur J Dermatol 2010;20:768-72.

14. Burris J, Rietkerk W, Woolf K: Relationships of self-reported dietary factors and perceived acne severity in a cohort of New York young adults. J Acad Nutr Diet 2014;114:384-92.

15. Di Landro A, Cazzaniga S, Cusano F, et al: Adult female acne and associated risk factors: Results of a multicenter case-control study in Italy. J Am Acad Dermatol 2016;75:1134-41

16. Karadağ AS, Balta I, Sarıcaoğlu H, et al: The effect of personal, familial, and environmental characteristics on acne vulgaris: a prospective, multicenter, case controlled study from Turkey. G Ital Dermatol Venereol 2019;154:17785. 